\title{
Less Smoke, More Mirrors: Where India Really Stands on Solar Power and Other Renewables
}

\section{David Wheeler and Saurabh Shome}

\begin{abstract}
Until recently, India's intransigent negotiating posture has conveyed the impression that it will not accept any carbon emissions limits without full compensation and more stringent carbon limitation from rich countries. However, our assessment of India's proposed renewable energy standard (RES) indicates that this impression is simply wrong. India is seriously considering a goal of 15 percent renewable energy in its power mix by 2020 , despite the absence of any meaningful international pressure to cut emissions, no guarantees of compensatory financing, and a continuing American failure to adopt stringent emissions limits. If India moves ahead with this plan, it will promote a massive shift of new power capacity toward renewables within a decade. We estimate the incremental cost of this change from coal-fired to renewable power to be about $\$ 50$ billion—an enormous sum for a society that must still cope with widespread extreme poverty. If India moves ahead with its current plan, it should give serious pause to those who have resisted U.S. carbon regulation on the grounds on that it will confer a cost advantage on "intransigent" countries such as India.
\end{abstract}




\title{
Less Smoke, More Mirrors: \\ Where India Really Stands on Solar Power and Other Renewables
}

\author{
David Wheeler \\ Senior Fellow \\ Center for Global Development \\ Saurabh Shome \\ Masters Candidate \\ School for Advanced International Studies \\ Johns Hopkins University
}

Many thanks to Matt Hoffman for his help with computations and editing. Thanks also to Arvind Subramanian and Kevin Ummel for valuable comments and suggestions. All remaining errors are our own.

This paper was made possible by financial support from the UK Department for International Development.

David Wheeler and Saurabh Shome. 2010. "Less Smoke, More Mirrors: Where India Really Stands on Solar Power and Other Renewables." CGD Working Paper 204. Washington, D.C.: Center for Global Development.

http://www.cgdev.org/content/publications/detail/1423937

Center for Global Development 1800 Massachusetts Ave., NW Washington, DC 20036

202.416 .4000

(f) 202.416 .4050

www.cgdev.org
The Center for Global Development is an independent, nonprofit policy research organization dedicated to reducing global poverty and inequality and to making globalization work for the poor. Use and dissemination of this Working Paper is encouraged; however, reproduced copies may not be used for commercial purposes. Further usage is permitted under the terms of the Creative Commons License.

The views expressed in this paper are those of the author and should not be attributed to the board of directors or funders of the Center for Global Development. 


\section{Introduction}

The past few months have witnessed an interesting development in the high-level discussion of climate policy in India. On October 19, 2009, the Times of India (Sethi, 2009) reported that India’s Environment Minister had privately urged the Prime Minister to scrap the Kyoto Protocol's “common but differentiated responsibilities," accept greenhouse gas reductions at India's own cost, without any guarantees of financial or technological support from developed countries, and permit strict external scrutiny of India's mitigation achievements. Adoption of this stance would be a radical departure from the public position taken by every Indian government since 1990. The Environment Minister's proposal remains controversial in India, but it may well be an indicator of changes to come.

What events have catalyzed this development? As Subramanian (2009) notes, several political considerations are in play. The first is India's great-power ambition. Elements include its new status as a G-20 member, its aspiration to secure a permanent seat on the UN Security Council, and its desire to avoid playing second fiddle to China in negotiations with the US. Some senior government officials apparently believe that a more accommodating stance on carbon emissions will enhance India's prospects in all these dimensions. Another factor is the perception that India has been losing the battle of the climate-change "narrative", in which it has forcefully argued that rich countries should shoulder the carbon mitigation burden because they have produced the climate problem. India's position has had little effect on the negotiating posture of the rich countries, and many respected international voices have continued urging India to join the mitigation effort. Finally, and possibly most important, the government has concluded that it should promote clean power anyway, in order to develop an internationally 
competitive supplier industry, to bolster energy independence, and to help limit climate change because it will pose dire threats to India itself (Cline, 2007).

Knowledge of these developments makes it easier to understand India's reaction to the US failure to enact cap-and-trade legislation, as well as the impasse at Copenhagen. Despite such setbacks, India has confounded expectations by moving to promote a low-carbon economy. Although economic growth, universal energy access and energy security remain critical concerns, Indian policymakers have increasingly engaged the climate issue. The government announced an ambitious National Action Plan on Climate Change in June 2008, with eight initiatives to support emissions mitigation. It has established an Advisory Council on Climate Change, led by the Prime Minister, and it is one of the few national governments to have a ministry dedicated to renewable energy. India announced an ambitious National Solar Mission in August, 2009, and the Ministry of New and Renewable Energy (MNRE) is currently drafting a National Renewable Energy Policy that will provide a regulatory framework for promoting clean energy development (EIU, 2009a). One important provision of this document is expected to be a national Renewable Energy Standard (RES) that will mandate an increasing percentage of total energy consumption from renewable sources.

To assess the significance of the proposed RES, this paper estimates the implied carbon emissions reduction and discusses its implications for India's international position. The remainder of the paper is organized as follows. Section 2 provides an overview of electricity generation and carbon emissions from India's power sector. In Section 3, we summarize recent Indian federal and state initiatives for renewable energy promotion. Section 4 assesses the magnitude of India's renewable energy commitment by estimating future carbon emissions reductions under the proposed national Renewable Energy Standard. Section 5 considers the 
implications for capacity expansion and cost, while Section 6 provides a summary and conclusions.

\section{Power Generation and Carbon Emissions in India}

Universal access to electricity remains a primary policy objective in India. In 2003 the Ministry of Power published "Mission 2012: Power for All," a plan for achieving universal access by 2012 through installation of 100,000 MW of new capacity. In 2007, India had a total installed capacity of about $130,000 \mathrm{MW}^{1}$, with the announced goal of adding about 80,000 MW by 2012 and 270,000 MW by 2030 (Chaliha, 2007). Most of India's power production is coalbased. Renewable sources account for only 9\% of capacity (Figure 1), and a much lower percentage of production when capacity utilization rates are taken into account. The average rate for a coal-fired power plant is about $80 \%$, while rates for renewable energy plants vary from $75 \%$ for biomass to $20 \%$ for wind. In all, renewable electricity accounts for only $1.7 \%$ of India's current generation, while coal-based generation accounts for nearly $70 \%$ (Figure 2). ${ }^{2}$

\section{Figure 1}

Installed Capacity (\%) 2009

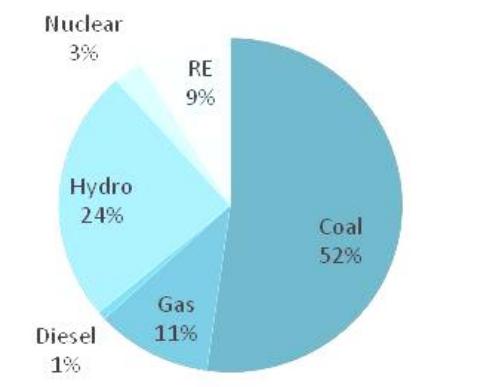

Source: Ministry of Power, Government of India

\footnotetext{
${ }^{1}$ Ministry of Power, Government of India.

2 Authors' estimate.
} 
Figure 2

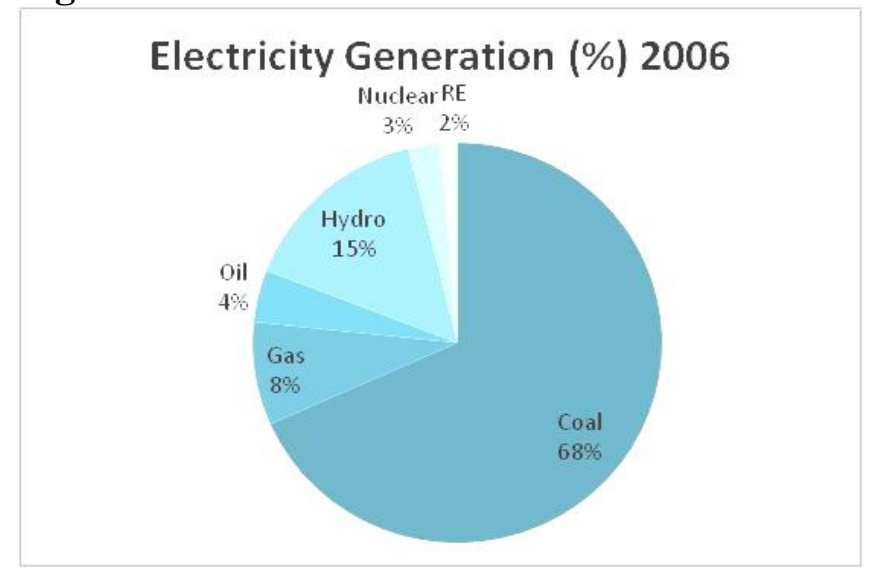

Source: World Bank, World Development Indicators, 2009

The low percentage of renewable energy reflects its relatively high cost, not realizable potential. India's renewable potential is estimated at about 585,000 MW, or almost four times its current total power generation capacity. As of 2009, only 14,500 MW of renewable capacity has actually been developed. ${ }^{3}$ Most of India's grid-interactive renewable power (excluding large hydro) comes from wind, small hydro and biomass. Nearly three-fourths is generated by wind (Figure 3). ${ }^{4}$

\section{Figure 3: Installed Capacity of Grid-Interactive Electricity From Renewable Sources (MW) 2009}

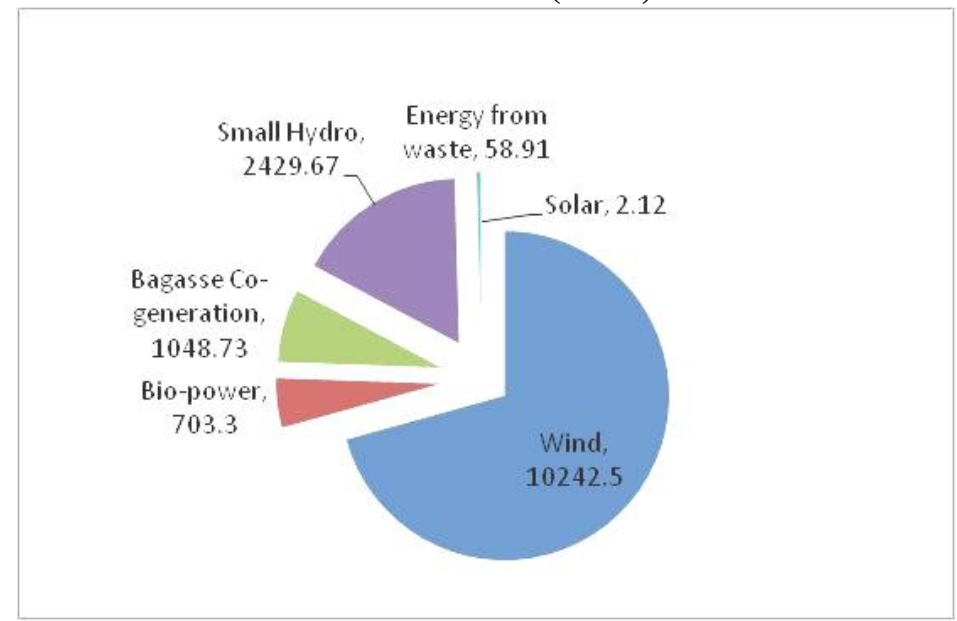

Source: Ministry of New and Renewable Energy, “Akshay Urja”, April 2009

\footnotetext{
3 “Akshay Urja”, April 2009, Ministry of New and Renewable Energy, Government of India.

4 Annual Report 2008, Ministry of New and Renewable Energy, Government of India.
} 
India's heavy use of coal largely explains its status as the fourth-biggest greenhouse gas (GHG) emitter in the world. India accounts for about 5\% of global GHG emissions from fossil fuel combustion, although its per capita emissions remain very low (1.7 mt CO2 equivalent, vs. 23.5 for the US, 10.3 for the EU, 10.5 for Japan and 5.5 for China). India's electricity and heat sectors account for almost 57\% of its total GHG emissions (WRI, 2009).

\section{Renewable Energy Initiatives}

Despite the relatively high cost of renewables, India's federal and state governments have recently promoted renewable energy, particularly solar power. In August 2009, the government published a "National Solar Mission" that aims to install 10,000 MW of solar capacity by 2020 (EIU, 2009b). The Ministry of New and Renewable Energy has adopted a renewable power strategy that includes budgetary support for research, development and demonstration projects; incentives for financial institutions to invest in renewables; and promotion of direct private investment through accelerated depreciation rates, sales tax exemptions, reduced import duties for related equipment, feed-in tariffs, and Renewable Energy Standards.

A Renewable Energy Standard (RES) is a mandated percentage of total electricity that must be generated from renewable sources. An RES program can involve various participants, including electricity generators, distributors and final consumers. A market is established by issuing renewable energy credits (RECs) to these stakeholders. The RECs can then be traded to fulfill the mandated standards, helping to lower the total cost of mitigation. At the end of a compliance period, usually a year, RECs are presented to the regulator as proof of compliance with the mandated RES. Participants have three options to achieve compliance: generation of energy from renewable sources; purchase of energy from renewable generators; or purchase of RECs to meet RES targets. 
During the past few years, renewable energy promotion policies have been incorporated into three major national reforms: the Electricity Act of 2003, the National Electricity Policy of 2005 and the National Tariff Policy of $2006 .^{5}$

\subsection{State-Level RES Policies}

Responding to these federal measures, 17 of India's 28 states have enacted RES policies. ${ }^{6}$

State RES mandates vary from $1 \%$ to $20 \%$ of total electricity, with compliance periods specified through 2011 or 2012. Regulations also vary considerably in their attention to detail. For example, Maharashtra clearly spells out implementation procedures and the compliance framework, while Himachal Pradesh and Bihar only stipulate percentage goals. The domain of application also varies. The majority of RES programs focus on state-owned enterprises, although a few programs include other power producers and consumers. Most state-level RES programs mandate that renewable power be procured only within the state. Gujarat's program is among the more advanced, with a planned market-based program that will enable participating entities to meet their obligations with purchased renewable energy certificates. ${ }^{7}$

At present, penalties for non-compliance with RES regulations are weak and, in many cases, avoidable. For example, Bihar allows non-compliance to be justified by "Force Majeure", and most other states permit non-compliance if renewable energy sources are deemed unavailable. In most statues, non-compliance is penalized by a maximum one-time charge of approximately \$US

\footnotetext{
${ }^{5}$ Electricity Act, 2003: Sec 81(1)(e) of the Electricity Act mandates that states specify a percentage of electricity to be purchased from renewable sources in order to promote the generation of renewable energy. Sec 61 (h) of the Act goes further, charging the State Electricity Regulatory Commissions (SERCs) with responsibility for regulating tariffs to promote sustainable generation from renewables.

National Electricity Policy, 2005: Para 5.2.20 commits the government to providing incentives for private-sector participation in renewable generation.

National Tariff Policy, 2006: Para 6.4 (1) recognizes that renewable sources need financial support until they can achieve market parity with conventional sources, and stipulates that appropriate Renewable Energy Standards should be established by the SERCs.

${ }^{6}$ The 17 states are Andhra Pradesh, Chattisgarh, Delhi, Gujarat, Haryana, Himachal Pradesh, Karnataka, Kerala, Madhya Pradesh, Maharashtra, Orissa, Punjab, Rajasthan, Tamil Nadu, Uttar Pradesh, Uttaranchal and West Bengal. ${ }^{7}$ GERC (draft regulation): Notification 1 of 2009 "Gujarat Electricity Regulatory Commission (Power Procurement from Renewable Sources) Regulations 2009", Para 9.0.
} 
2000 for each violation, and/or a daily penalty not exceeding \$US 120 until compliance is

achieved. These sanctions are significantly less than the additional cost of procuring electricity from renewable sources. ${ }^{8}$

In summary, India's state governments have responded to recent national initiatives with programs that vary widely in focus and ambition, and with enforcement sanctions that are quite weak. Although the state-level measures are noteworthy, they seem too weak to catalyze largescale renewable investment by India's power producers. However, recent developments at the national level suggest that more ambitious measures are imminent.

\subsection{National RES Policy}

There are strong indications that India will soon adopt a national RES policy that will bring more clarity, consistency and ambition to national renewable strategy. At a recent international conference, the chairman of the Central Electricity Regulatory Commission (CERC) cited a tentative plan to introduce a nationwide RES of $5 \%$ for grid power purchased by state utilities by 2010, with an increase to $15 \%$ by 2020 (Business Standard, 2009). This plan has been proposed after submission of recommendations on national policy in November, 2008 by a working group of the National Forum of Regulators

\section{The Potential Impact of the National Renewable Energy Standard}

To gauge the potential impact of such a national RES, we quantify the emissions reductions that could be achieved by the CERC chairman's proposed target of $15 \%$ renewable energy by 2020. We construct two scenarios, Business as Usual (BAU) and RES (15\% by 2020).

BAU Scenario: To estimate the BAU energy mix in 2020, we project using growth trends since power-sector restructuring and the advent of significant privatization in 1991. Table 1

\footnotetext{
${ }^{8}$ Electricity Act 2003, Section 142.
} 
summarizes our results by energy source. In 2020, coal's share remains essentially unchanged at 68\%. Oil, gas and nuclear energy have all expanded their shares, while the share of large hydro has fallen from $15.3 \%$ to $9.9 \%$. Renewables have exhibited rapid growth, but from a low base, reaching a share of $3.5 \%$ by 2020 .

We translate these shares to emissions estimates in several steps. First, we forecast India's power requirement in 2020 by adopting the projection for 2021-22 by the Central Electricity

Table 1: Fuel Mix for Electricity Generation: 2006 and 2020

\begin{tabular}{|l|r|r|}
\hline Fuel & \multicolumn{1}{c|}{$\begin{array}{c}\% \\
\text { Coal }\end{array}$} & \multicolumn{1}{c|}{$\begin{array}{c}\text { 2006 } \\
2020\end{array}$} \\
\hline Oil & 68.32 & 68.45 \\
\hline Gas & 4.23 & 4.91 \\
\hline Nuclear & 8.34 & 10.12 \\
\hline Large Hydro & 2.50 & 3.10 \\
\hline Renewables & 15.27 & 9.88 \\
\hline
\end{tabular}

Authority (CEA): $1,914,508 \mathrm{GWh} .{ }^{9}$ Then we adjust for projected transmission and distribution (T\&D) losses, which are among the highest in the world. In 2006, they amounted to $25.4 \%$ of Indian power production. ${ }^{10}$ These losses have exhibited a downward trend (Figure 4) since the government launched its Accelerated Power Development and Reform Program in 2001. For our projection, we adopt the CEA's estimate of 16\% T\&D losses in 2020.

\footnotetext{
${ }^{9} 17^{\text {th }}$ EPS Report, CEA.

${ }^{10}$ World Bank, World Development Indicators, 2009.
} 
Figure 4: Transmission and Distribution Losses

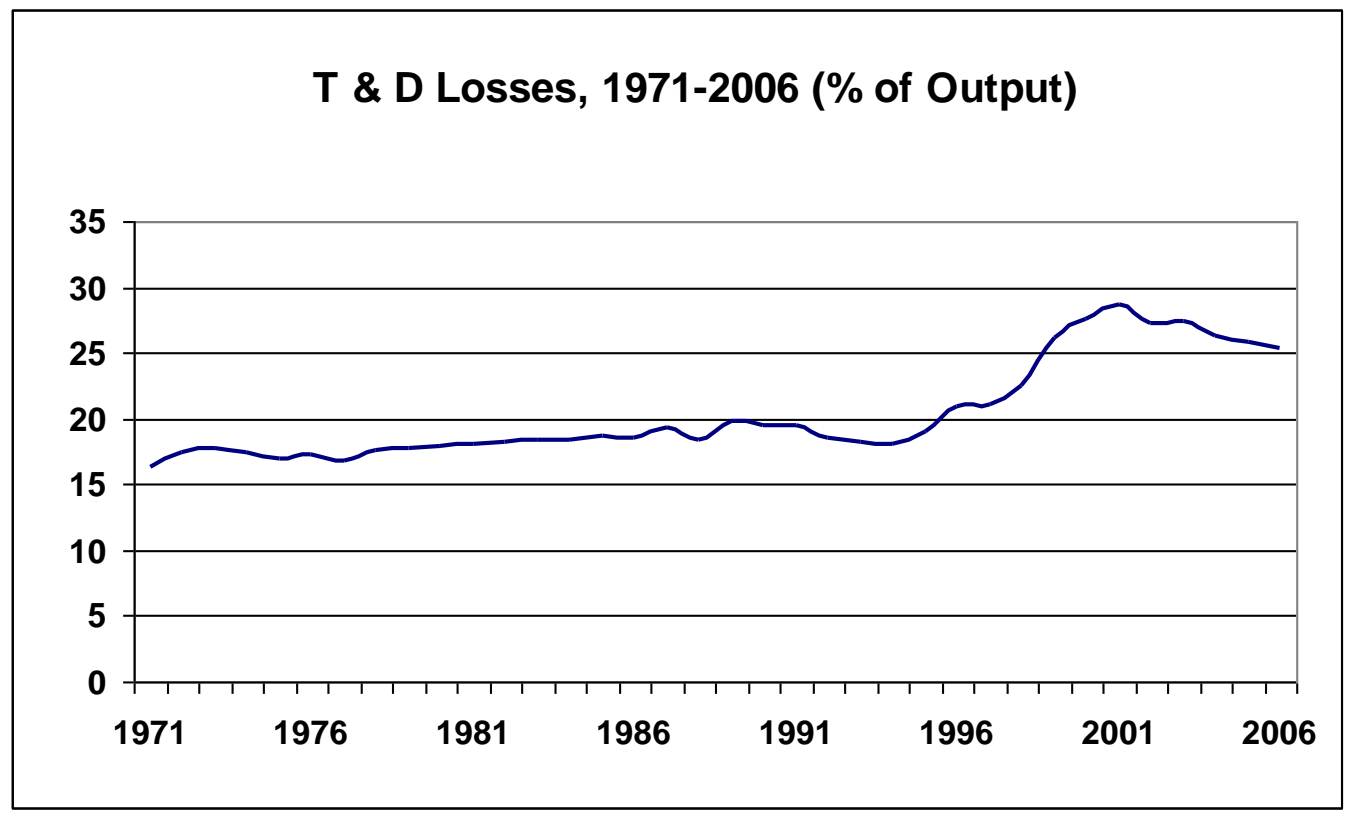

Source: World Bank, World Development Indicators, 2009

With our projected power requirement and T\&D loss rate, we estimate that India will have to generate 2,064,692 GWh of electricity in 2020 (Figure 5). This will require annual growth of 7.6\% from 2006 until 2020, compared to growth of 5.9\% from 1991 to 2006.

To project the associated $\mathrm{CO} 2$ emissions, we use fuel-specific $\mathrm{CO} 2$ intensities provided by the CEA in its baseline emissions database. ${ }^{11}$ In the BAU scenario, $\mathrm{CO} 2$ emissions from the power sector grow from 576 million tons in 2006 to 1,627 million tons in 2020.

RES Scenario: We adopt a best-case Renewable Energy Standard scenario, in which all increased generation from renewable sources offsets generation from coal, the most CO2intensive fuel. In our RES scenario, increasing the renewable percentage to $15 \%$ by 2020 reduces the coal-fired percentage to 57\%. The accompanying $\mathrm{CO} 2$ emissions increase from 576 million tons in 2006 to 1,380 million tons in 2020 (Table 2, Figure 6). By 2020, the difference

\footnotetext{
${ }^{11}$ Central Electricity Authority, Ministry of Power "Baseline Carbon Dioxide Emissions From Power Sector" Version 4.0. http://www.cea.nic.in/planning/c\%20and\%20e/Government\%20of\%20India\%20website.htm
} 
Figure 5: Indian Electricity Generation

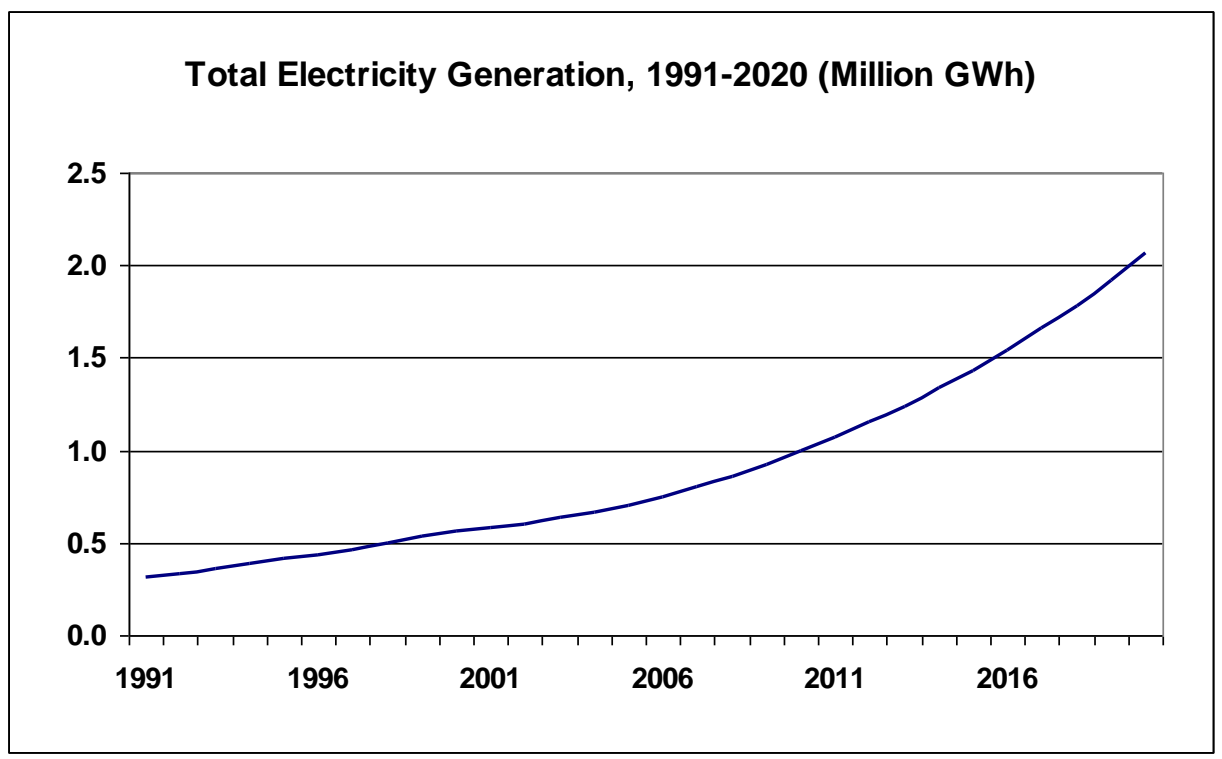

between BAU and RES is 247 million tons of $\mathrm{CO} 2$ per year (a 15.2\% reduction from BAU levels). The total difference in emissions for the period 2010-2020 is 1,324 million tons of CO2. This is a large reduction from the baseline, equivalent to about half the $2005 \mathrm{CO} 2$ emissions from electricity and heat production in the US or China (WRI/CAIT, 2009).

\section{Implications for Capacity Expansion and Cost}

To assess the implications of such a large change, we have to translate the associated fuelbased electricity projections into installed capacities using plant load factors (PLFs -- capacity utilization rates). Overall, the average PLF for thermal power plants in India has increased from $64.6 \%$ in $1998-99$ to $78.8 \%$ in $2007-2008 .^{12}$ For this study, we assume a future PLF of $80 \%$ for thermal plants, as well as for nuclear and large hydro facilities. Taking a weighted average of PLFs for renewable power plants, we assume an overall PLF of $28 \%$ for renewables.

\footnotetext{
12 "Performance Review of Thermal Power Stations 2007-08” CEA, Government of India.
} 
Table 2: Electricity Generation and CO2 Emissions by Fuel Source, 2020

\begin{tabular}{|l|r|r|r|r|}
\hline \multicolumn{4}{|c|}{$\begin{array}{c}\text { Generation and Emissions } \\
\text { (Thousand }\end{array}$} & \multicolumn{2}{c|}{$\begin{array}{c}\text { Emissions } \\
\text { (Million tCO2) }\end{array}$} \\
\hline Fuel & BAU & \multicolumn{1}{|c|}{ RES } & BAU & \multicolumn{1}{l|}{ RES } \\
\hline Coal & 1,413 & 1,177 & 1,470 & 1,224 \\
\hline Oil & 101 & 101 & 67 & 67 \\
\hline Gas & 209 & 209 & 90 & 90 \\
\hline Hydro & 204 & 204 & 0 & 0 \\
\hline Nuclear & 64 & 64 & 0 & 0 \\
\hline Renewables & 73 & 310 & 0 & 0 \\
\hline Total & 2,065 & 2,065 & 1,627 & 1,380 \\
\hline
\end{tabular}

Figure 6: CO2 Emissions from India's Power Sector

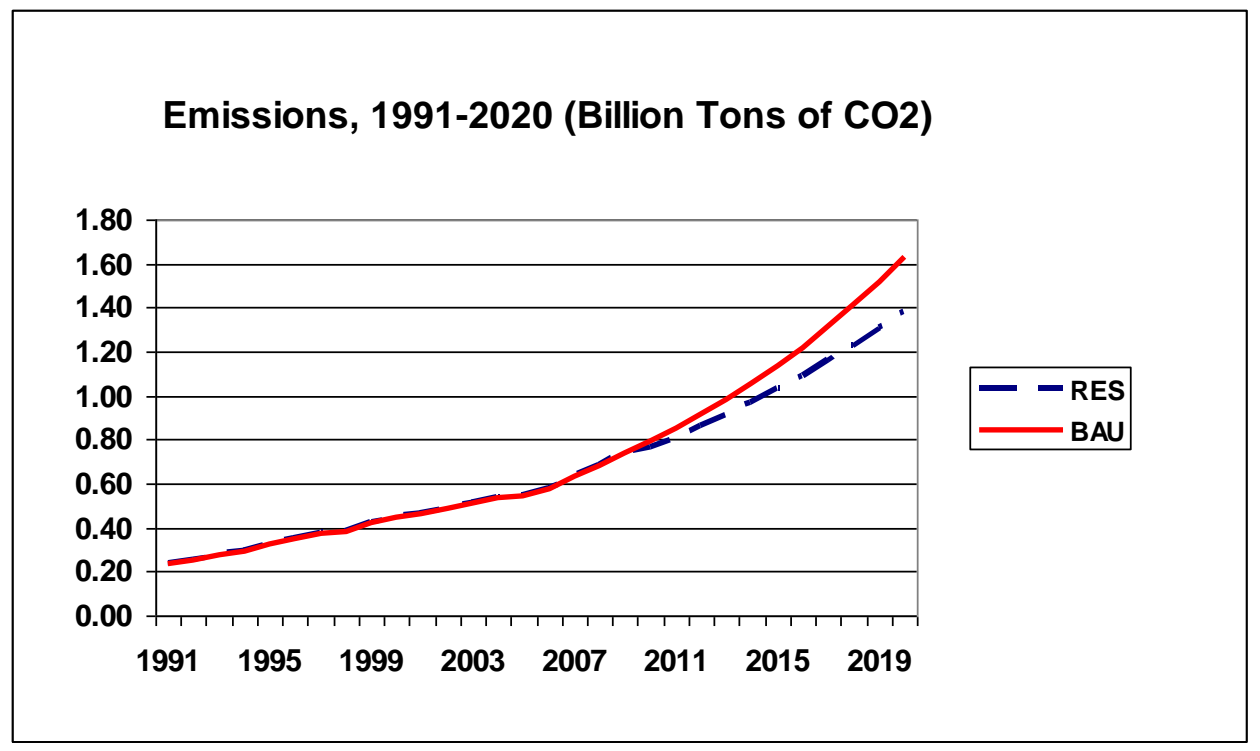

With these PLFs, meeting the power generation target of 2,064,692 GWh in 2020 would require a total installed capacity of 313,951 MW in the BAU scenario, approximately double the current capacity. The capacity of renewable power plants would be 29,741 MW, about twice the current renewable capacity, representing 5\% of India's total estimated renewable potential.

Meeting the same power generation target in the RES scenario would require a total installed capacity of $376,700 \mathrm{MW}$, with renewable capacity increasing to 126,265 MW - about 8.7 times current renewable capacity, and about $21.6 \%$ of India's total renewable potential (Figure 7). 
Figure 7: Installed Capacity by Fuel Source, BAU and RES Scenarios, 2020

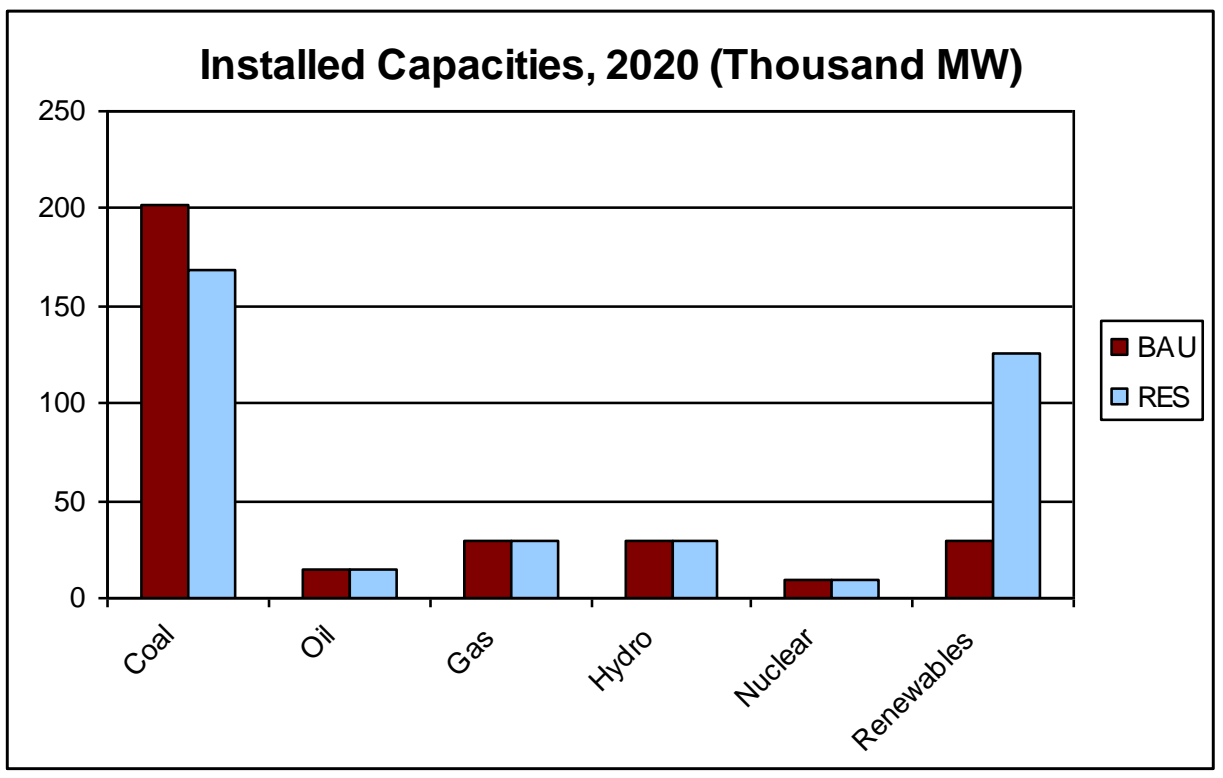

Assuming equal annual increments, achieving the RES target of 15\% renewable energy by 2020 would require India to increase its renewable energy capacity by approximately 10,000 MW every year from 2009 to 2020. These annual increments have the same order of magnitude as India's current renewable capacity.

We assess the potential cost implications of the RES using the most recently published cost estimates for power production by supercritical coal plants, concentrating solar power (CSP) facilities ${ }^{13}$ and wind turbines. ${ }^{14}$ Indian costs for coal, large-scale CSP and wind are currently about 5, 13 and 7 US cents/kWh, respectively. ${ }^{15}$ Each cent/kWh difference between renewable power and coal translates to an equivalent emissions charge of about $\$ 10 /$ ton $\mathrm{CO} 2,{ }^{16}$ so

\footnotetext{
${ }^{13}$ Source: Ummel and Wheeler (2008), Table 2. Concentrating solar power facilities use mirror arrays to concentrate solar energy on boilers that drive conventional steam turbines.

${ }_{15}^{14}$ Pillai and Banerjee (2009), Table 8.

${ }^{15}$ We use the average estimate for wind power cost in Pillai and Banerjee (2009), Table 8. The cost for concentrating solar power (CSP) includes thermal storage. Recent public statements by eSolar suggest that our estimate for CSP is higher than current best practice. At present, however, we have no independent evidence that this claim is correct.

${ }^{16}$ We derive the estimate of $\$ 10 /$ ton CO2 as follows: One cent $/ \mathrm{kWh} \Rightarrow \$ 10 / \mathrm{MWh}$, and coal-fired plants emit approximately 1 ton $\mathrm{CO} / \mathrm{MWh}$. So an additional cent/kwh incurred for renewable power is equivalent to imposing a charge of $\$ 10 /$ ton $\mathrm{CO} 2$ on coal-fired power.
} 
substituting the two renewable technologies for coal-fired power is equivalent to accepting carbon emissions charges of $\$ 80 /$ ton CO2 for CSP and $\$ 20 /$ ton for wind. ${ }^{17}$ Wind power is a relatively mature technology, so we expect its cost to be approximately stable through 2020. But we believe that learning and scale economies for CSP will reduce its cost difference from coalfired power to about 4 cents/kWh, equivalent to a marginal carbon emissions charge of \$40/ton. Assuming a linear cost decline, the average for the period 2010-2020 would be $\$ 60 /$ ton.

In Section 4, we have estimated that India's adoption of a 15\% RES would avert about 1.3 gigatons of CO2 emissions during the period 2010-2020. If CSP expansion accounted for the entire switch from coal-fired to renewable energy, with an average cost differential of 6 cents/kWh, India's adoption of the $15 \%$ RES would be equivalent to maintaining its BAU power expansion with a total $\mathrm{CO} 2$ charge of about $\$ 80$ billion for emissions from new coal-fired power facilities during the period 2010-2020. In the case of wind power, the total CO2 charge would be about $\$ 27$ billion. If we assume equal shares in renewable energy growth for CSP and wind, the total will be about $\$ 54$ billion -- a huge cost that will be voluntarily borne by India if the proposed national RES is adopted. ${ }^{18}$

\section{Summary and Conclusions}

Until recently, India's intransigent negotiating posture has conveyed the impression that it will not accept any carbon emissions limits without full compensation by rich countries and the adoption of more stringent carbon limitations by those countries. However, our assessment of

\footnotetext{
${ }^{17}$ Here we assume that investors would switch from coal-fired power to the renewable technology at the given $\mathrm{CO} 2$ charge, since it would increase the coal-fired power cost to parity with the renewable cost.

${ }^{18}$ India's cost burden would be substantially lower if Clean Development Mechanism (CDM) financing were available for investments under the National Solar Plan and other plans. However, in a surely unintentional but nonetheless astonishing lapse, the CDM rules mandate payments only for projects that would not have been constructed without the payments. Since the anticipated Indian projects do not meet this condition, they apparently do not qualify for CDM financing. We believe that future reforms of the CDM should include correcting this unfortunate Catch-22.
} 
India's proposed national RES indicates that this impression is simply wrong. India is giving serious consideration to adoption of a $15 \%$ RES for its own reasons, despite the absence of any meaningful international pressure to cut emissions, no guarantees of compensatory financing, and a continuing American failure to adopt stringent emissions limits. If India moves ahead with this plan, it will promote a massive shift of new power capacity toward renewables within a decade. As we have shown, the change will be cost-equivalent to India's acceptance of a total $\mathrm{CO} 2$ charge of about $\$ 50$ billion for staying on the BAU path that its international posture has seemed to support. This is an enormous cost that will be voluntarily borne by a society that must still cope with widespread extreme poverty. If India moves ahead with its current plan, it should give serious pause to those who have resisted US carbon regulation on the grounds on that it will confer a cost advantage on "intransigent" countries like India. 


\section{References}

Business Standard. 2009. "Buy at least 5\% renewable energy: CERC orders state utilities." June 18. http://www.business-standard.com/india/news/buy-at-least-5-renewable-energy-cerc-ordersstate-utilities/00/29/64975/on

Chaliha, Kumar Amitav. 2007. Indian Electricity: Miles to Go. KWR Special Report, August 20. http://www.kwrintl.com/library/2007/indianelectricity.htm

Cline, William. 2007. Global Warming and Agriculture: Impact Estimates by Country. Washington: Center for Global Development and Peterson Institute for International Economics.

EIU (Economist Intelligence Unit). 2009a. India Energy: Piecemeal Reforms. June 1.

EIU (Economist Intelligence Unit). 2009b. India Alternatives: Government Backs Solar Plan. August.

Pillai, Indu and Rangan Banerjee. 2009. Renewable Energy in India: Status and Potential. Energy (34): pp. 970-980.

Sethi, Nitin. 2009. Jairam for major shift at climate talks. Times of India, October 19.

Subramanian, Arvind. 2009. India: New Letter and Spirit. Op-ed in Business Standard, New Delhi. October 28.

http://www.petersoninstitute.org/publications/opeds/oped.cfm?ResearchID=1317

Ummel, Kevin and David Wheeler. 2008. Desert Power: The Economics of Solar Thermal Electricity for Europe, North Africa, and the Middle East. Center for Global Development Working Paper No. 156.

World Bank. 2006. Can Good Economics Ever Be Good Politics? Case Study of India's Power Sector. Washington, DC: World Bank.

WRI. 2009. Climate Analysis Indicators Tool (CAIT), Version 6.0. Washington, DC: World Resources Institute. http://cait.wri.org/ 